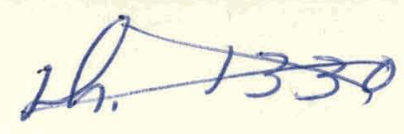

\title{
Instruction and Information on Used Energy-Related Laboratory Equipment Grants for Educational Institutions of Higher Learning
}

United States Department of Energy Office of Energy Research University \& Industry Programs Division Washington, D.C. 20585

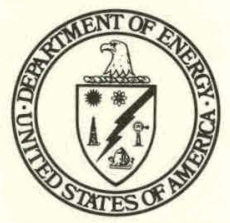

February 1980 


\section{DISCLAIMER}

This report was prepared as an account of work sponsored by an agency of the United States Government. Neither the United States Government nor any agency Thereof, nor any of their employees, makes any warranty, express or implied, or assumes any legal liability or responsibility for the accuracy, completeness, or usefulness of any information, apparatus, product, or process disclosed, or represents that its use would not infringe privately owned rights. Reference herein to any specific commercial product, process, or service by trade name, trademark, manufacturer, or otherwise does not necessarily constitute or imply its endorsement, recommendation, or favoring by the United States Government or any agency thereof. The views and opinions of authors expressed herein do not necessarily state or reflect those of the United States Government or any agency thereof. 


\section{DISCLAIMER}

Portions of this document may be illegible in electronic image products. Images are produced from the best available original document. 
Available from:

National Technical Infurmation Service (NTIS) U.S. Department of Commerce

5285 Port Royal Ruad

Springfield, Virginia 22161

Price: Printed copy: Microfiche:

$5 \cdot 00$

3.00

$\$ 3.0050$ 


\section{Instruction and Information on Used Energy-Related Laboratory Equipment Grants for Educational Institutions of Higher Learning}

\section{United States}

Department of Energy

Office of Energy Research

University \& Industry

Programs Division

Washington, D.C. 20585
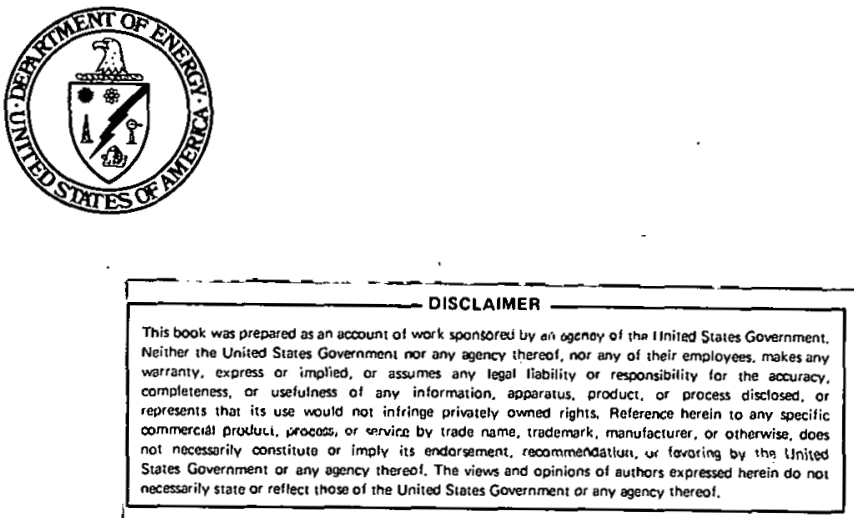

February 1980 


\section{THIS PAGE}

WAS INTENTIONALLY

LEFT BLANK 


\section{USED ENERGY-RELATED LABORATORY EQUIPMENT GRANTS}

The United States Department of Energy (DOE), in accordance with its responsibility to encourage research and development in the energy area, awards grants of used energyrelated laboratory equipment to universities and colleges and other non-profit educational institutions of higher learning in the United States for use in energy-oriented educational programs in the life, physical and environmental sciences and engineering.

Proposals for the grant of available equipment in this program should be submitted by an eligible non-profit educational institution to the DOE Field Office responsible for the site where the specific equipment is known to be located.

\section{Ellglbility and Procedure}

Any non-profit educational institution of higher learning, such as a university, college, junior college, hospital, and technical institute and museum, located in the United States and interested in establishing or upgrading energy-oriented educational programs in the life, physical and environmental sciences and engineering is eligible. High schools, grade schools and vocational trade schools are excluded. An energy-oriented program is one that deals partially or entirely in energy-related topics.

Lists of equipment are available for review by educational institutions at any of the sites listed in Appendix A: These lists cannot be removed from the site premises. Continuous daily changes in the available equipment shown on them preclude duplication and distribution to an educational institution. The responsibility for reviewing and locating specific equipment on these lists rests solely with the requesting institution, and therefore, any telephone or written requests to contractor or DOE for special attention in locating equipment cannot be honored. Advance appointments should be made prior to a visit to one of the designated sites to review the equipment lists.

After the equipment lists have been reviewed and specific equipment located and "earmarked," a proposal should be prepared for submission to designated DOE Field Offices, as shown in Appendix B. Because of the problem and cost of equipment storage 
and the continuous demand by other Federal agencies for equipment, a maximum period of 30 days will be permitted from the time of "earmarking" the equipment to the time of receipt of a proposal. The review of proposals and the awarding of equipment grants by the responsible representatives of DOE will be accommodated on a first-received, first-qualified basis.

The cost of care and handling incident to the grant must be borne by the institution; such costs normally consist of packing; crating, shipping and insurance, and are limited to actual costs. Arrangements for shipment and the reimbursement of any of the aforementioned actual costs should be coordinated between the institution and each of the DOE installations responsible for the equipment; these arrangements should be initiated by the requesting institution within one week after receipt and acceptance of the grant by the institution. The cost of any repairs and/or modifications to any equipment will be borne by the reclpient institution.

Note: Responsibility for location of specific equipment rests with the requesting institution. Specific inquiries ooncerring equipment are to be ulrected to the office handling university relations at the DOE Field Offices. General inquiiries may be made to the [IOE'E Educiatlon Programs Division, Washington, D.C. 20545. Proposals for the grant of specific equipment may be submitted by any college or university to the appropriate DOE Field Office.

\section{TYPICAL EQUIPMENT}

Typical items of educational training apparatus or equipment which may be requested are listed below. It should be emphasized that these examples are merely illustrative and not inclusive.

radiation detectors. monitors, ecalers, and counters nuclear reactors and accelerators neutron howitzers and generators critical and subcritical assemblies bubble and cloud chambers dosimeters, survey meters, radiometers, and spectroscopes radiation shields and reactor associated components mass spectrometers, infrared spectrometers, and ultraviolet spectrometers gas and liquid chromatographs ammeters, voltmeters, electrometers linear and pulse-height analyzers power supplies catalyst test unils distillation columns temperature and pressure recorders 
Title to such equipment when granted by the DOE will vest with the educational institution.

Note: Neutron sources and other radioactive materials will not be included unless they are essential components of the equipment to be granted. As such, the source materials must have been specifically designed for the particular equipment. Nuclear materials may be loaned to colleges and universities through a Nuclear Materials Loan Program administered by the DOE's Education Programs Division.

The following list is illustrative of the type of equipment or purposes for which equipment will not be provided.

1. General supplies.

2. Equipment intended by the institution for contractual project research.

3. Furniture, such as desks, tables, chairs, conventional laboratory benches, typewriters, etc. (except as such equipment may be an essential component of and physically attached to an energy-related laboratory equipment system).

4. Refrigerators, tools, etc.

5. Computing equipment.

6. Equipment determined to be required by other DOE laboratories.

\section{INSTITUTIONAL COSTS}

Packing, crating and shipping charges are to be borne by the institution requesting the grant. The handling of these charges should be coordinated between the institution and the DOE installation possessing the equipment. The costs of repairs and modifications to any equipment are to be borne by the institution.

\section{PROPOSAL GUIDE}

Proposals for grants of used energy-related laboratory equipment for either undergraduate programs or graduate programs should generally follow the format outlined below:

\section{Proposal Objectives}

Provide a brief statement relative to the type of equipment needed and indicate whether any discussions concerning such equipment have been held with the laboratory or other DOE facility personnel. 
2. Energy-Oriented Science and-Engineering Education Program

Include a brief description of the energy-oriented science and engineering education program of which the proposed equipment would be a part and any specific experiments planned for its use.

3. Courses

Please provide the following for each course of which the proposed equipment would be a part:

Course Number

Educational Level-Undergraduate: 1, 2, 3, 4, Graduate: M.S., Ph.D.

Title

Description

Enrollment (show for several years)

Frequency of offering

4. Graduate Degrees Awarded

Graduate Programs: Please show the number and level (M.S., Ph.D.) of degrees awarded within the area to be supported for the past five years.

5. Data on Present Facility

For each faculty member participating in the proposed laboratory program, please list the following information:

Name Degree

Brief description of background and experience related to subject of equipment application.

6. Prior Grants

Reference should be made to any prior federal educational assistance grant for equipment (financial or otherwise) to the same or to a related department. Explain the relationship, if any, to the currently requested equipment and to the proposed program. 


\section{Certifications}

The following certifications should be provided:

a. A statement that the institution will utilize the requested equipment for energy-related instructional purposes in regularly scheduled laboratory and instructional courses.

b. A statement that the conditions as set forth below are included as a part of the grant agreement.

\section{TERMS AND CONDITIONS}

When a grant is executed, the following Terms and Conditions will apply:

“GRANT NO. is placed in accordance with and subject to the following terms and conditions:

1. The term "grantee" as used herein means the educational institution receiving this grant. The term "DOE" means the "United States Department of Energy" and its duly authorized representatives. The phrase "persons acting on behalf of the DOE" includes authorized contractors of the DOE and their duly authorized representatives. The term "equipment" as used herein means the used items described on the face hereof as the item(s) being granted. The term "DOE Facility" means the laboratory, plant, or office, operated by. or on behalf of the DOE, in possession and/or responsible for each equipment item shown on the face hereof.

2. The grantee understands that the DOE may fulfill its obligations under this grant through any DOE Facility(s).

3. The grantee agrees to pay for all costs of packing, normal and special handling crating and shipping, and agrees to coordinate the costs and any payments with the DOE Facility.

4. The grantee will be responsible for any repair and modification costs to any equipment received under this grant.

5. The grantee agrees to provide shipping instructions to and arrange for the payment of shipping costs with the cognizant DOE Facility(s) within one week from acceptance of this grant. 
6. Neither the Government, DOE , nor persons acting on behalf of the DOE make any warranty or other representation, express or implied, that the equipment granted under this program will accomplish the results for which it is requested or intended.

7. The grantee hereby releases and agrees to hold the Government, DOE , or persons acting on behalf of the DOE harmless for any and all liability of every kind and nature whatsoever resulting from the receipt, shipping, installation, operation, handling, use and maintenance of the equipment after said equipment is physically removed from the DOE Facility(s).

8. The grantee will utilize the granted equipment primarily for energy-related instructional purposes in regularly scheduled laboratory and instructional courses.

9. The grant of any nuclear equipment granted hereunder does not relieve the grantee from complying with the Atomic Energy Act of 1954, as amended, and the regulations issued pursuant theroto, includirig any requirements for permits and licenses, with respect to such equipment. (See especially, regulations of the Nuclear Regulatory Commission, Chapter 1, Title 10, Code of Federal Regulations.)

10. The disposition of any patents or inventions or discoveries resulting from the use of the equipment granted hereunder shall be the responsibility of the grantee, provided that the grantee shall give the Government an irrevocable, royalty-free non-exclusive license for use of such inventions, or discoveries for governmental purposes. (To the extent that DOE has any rights in such inventions or discoveries pursuant to Section 152 of the Atomic Energy Act of 1954, as amended, the DOE hereby waives such rights.) The grantee hereby waives all claims for damages under Section 183 of Title 35 U.S. Code by reason of the imposition of any secrecy order on any patent application, and also any clairn for just compensation or award, under the Atomic Energy Act of 1954 , as amended, with respect to any invention or discovery made or conceived in the course of or in connection with work performed with the granted equipment.

11. The grantee agrees to comply with the DOE's rogulatiur is (Part 4 of Title 10, Chapter I, of the Code of Federal Regulations), as amended, implementing (lie provisions of Title VI of the Civil Rights Act of 1964.

12. At the end of the first year of use of the equipment, the institution agrees to provide the DOE with a report on 
the use of the equipment; such reports will describe (1) any new courses instituted as a result of the grant of the equipment, (2) existing courses which have been expanded as a result of the grant of the equipment; or (3) other ways the equipment has been used to enhance courses, i.e., experiments, etc.

13. The grantee in signing this grant accepts the grant its terms and conditions and acknowledges that this agreement and the proposal referenced herein comprise the total agreement between the grantee and the DOE ." 


\section{Appendix A WHERE TO REVIEW EQUIPMENT LISTS}

\section{CALIFORNIA}

Property Administration Atomics International Division Rockwell International Corporation P.O. Box 309

Canoga Park, California 91304 Attn: Mrs. Louise Hof

(213) 341-1000, Ext. 1911

Property Manager

Lawrence Berkeley I ahoratory

University of California

Berkeley, California 97420

Attn: Mr. Wm. Hesson

(415) $486-4124$

Business Services, L-145

Lawrence Livermore Laboratory University of California

Livermore, California 94550

Attn: C. L. Blue

(415) $422-8404$

Department of Energy

7th Floor

333 Market Street

San Francisco, California 94105

Attn: Energy Resources Center (415) 566-0305

\section{COLORADO}

Rocky Flats Area Office

United States

Department of Energy

P. O. Box 928

Golden, Colorado 80401

Attn: Mr. Dón Ofte

Area Manager

(003) 497-2025

\author{
Department of Energy \\ P.O. Box 26247 \\ Belmar Branch \\ 1075 S. Yukon \\ Lakewood, Colorado 80226 \\ Attn: Mr. Epifino Vallejo \\ (303) 234-2480
}

\section{DISTRICT OF COLUMBIA}

\author{
Department of Fnergy \\ R̄oom 5-B-180 \\ 1000 Independience Ave., 3.W. \\ Waohingtüı, D.C. 20585 \\ Attn: Ms. Verlette Gatlin \\ (202) 252-5969
}

\section{GEORGIA}

\author{
Department of Energy \\ 1655 Peachtree Street, N.E. \\ 8th. Floor \\ Atlanta, Georgia 30309 \\ Attn: Mr. Brian Coyne \\ (404) $881-4463$
}

\section{IDAHO}
Property Management Branch EG\&G Nuclear Company 550 Second Street Idaho Falls, Idaho 83401 (208) 526-1300

\author{
Property Management and \\ AdmInistrative Services Branch \\ Idaho Operations Office \\ United States \\ Department of Energy \\ 55u Second Street \\ Idaho Falls, Idaho 83401 \\ Attn: J. P. Anderson \\ (208) 526-1.308
}


ILLINOIS

Supply Division, Property

Management

Argonne National Laboratory

9700 South Cass Avenue

Argonne, Illinois 60439

Attn: Mr. Hank Jurgensen

(312) 972-2780, Ext. 4655

Chicago Operations

and Regional Office

Department of Energy

Room A-1136

175 West Jackson Boulevard

Chicago, Illinois 60604

Attn: Ms. Gina Holman

(312) 353-5779

IOWA

Materials Handling and Property Office

Room 152, Spedding Hall

Ames Laboratory

lowa State University

Ames, lowa 50011

Attn: T.F. Rush

(515) 294-1780

\section{MASSACHUSETTS}

Department of Energy

150 Causeway St.

Room 700

Boston, Massachusetts 02114

Attn: Ms. Kathy Healy

(617) 223-5257

\section{MISSOURI}

Kansas City Area Office

United States

Department of Energy

P. O. Box 202

Kansas City, Missouri 64141

Attn: Mr. Robert Bulcock,

Area Manager

(816) $997-3341$

Department of Energy

23rd. Floor

324 E. 11th. St.

Kansas City, Missouri 64106

Attn: Mr. F. Gilbert Lagergren

(816) 374-5184

\section{NEVADA}

Property Management Nevada Operations Office

United States

Department of Energy

P. O. Box 14100

Las Vegas, Nevada 89114

Attn: Mr. John Smits

(702) 734-3564

\section{NEW MEXICO}

University Relations Division 4231

Sandia Laboratories

P.O. Box 5800

Albuquerque, New Mexico 87115

Attn: J.C. Tidmore

(505) 264-2838

\section{NEW YORK}

Property Management

Building 211

Brookhaven National Laboratory

Upton, Long Island, New York 11973

Attn: Mrs. Grace Fales

(516) 345-2123, Ext. 2977

Department of Energy

26 Federal Plaza

Room 3200

New Y.ork, New York 10007

Attn: Mr. William Wood

Administrative Officer

(212) 264-1021

\section{OHIO}

Property Management

Mound Laboratory

Monsanto Research Corporation

P.O. Box 32

Miamisburg, Ohio 45342

Attn: Donald O'Connor

(513) 865-3988

\section{PENNSYLVANIA}

Department of Energy

1421 Cherry Street

10th. Floor

Philadelphia, Pennsylvania 10102

Attn: Mr. Brian Coyne

(215) 597-9066 


\section{SOUTH CAROLINA}

University Relations Office

Savannah River Laboratory

E. I. du Pont de Nemours and Company

Aiken, South Carolina 29801

Attn: Mr.E.G. Swingle

(803) 725-3053

TEXAS

Department of Energy

P.O. Box 35228

2626 Mockingbird Lane

Dallas, Texas 75235

Attn: Mr. Marvin E. DeMoss

Director

Office of Management and Support

(214) 767-7701

\section{TENNESSEE}

Mąterialo Departiiiemıl

Oak Ridge National Laboratory

P.O. Box X

Oak Ridge, Tennessee 37830

Attn: Mr. W. O. Graves

(615) 574-4370

\section{WASHINGTON}

Excess Utilization

Atlantic Richfield Hanford Company

Building 1167-A

P.O. Box 250

Richland, Washington 99352

Attn: Marv McCollom

(509) 942-6706

Department of Energy

1992 Federal Building

915 Second Avenue

Seattle, Washington 98174

Attn: Ms. Ellen McCraney

(206) 442-5969 


\section{Appendix B \\ WHERE TO MAIL PROPOSALS FOR USED EQUIPMENT GRANTS}

One copy of the proposal for each site where equipment is located should be sent to the responsible DOE Field Office as shown:

Mail to Following ERDA Otfice:

H. E. Roser, Manager

Albuquerque Operations Office United States

Department of Energy

P.O. Box 5400

Albuquerque, New Mexico 87115

(505) 844-7231

Robert H. Bauer, Manager

Chicago Operations Office

United States

Department of Energy

9800 South Cass Avenue

Chicago, Illinois 60439

(312) $972-2000$

Charles E. Williams, Manager

Idaho Operations Office

United States

Department of Energy

550 2nd Street

Idaho Falls, Idaho 83401

(202) 526-1322

Mahlon E. Gates, Manager

Nevada Operations Office

United States

Department of Energy

P.O. Box 14100

Las Vegas, Nevada 89114

(702) 734-3211
If Equipment is Located at:

Bendix Corporation (Missouri)

Dow Chemical Company (Colorado)

General Electric Company (Florida)

Lovelace Biomedical and Environmental

Research Laboratories (New Mexico)

Los Alamos Scientific Laboratory (New Mexico)

Mound Laboratory Ohio)

Sandia Laboratories (New Mexico)

ZIA Company (New Mexico)

Ames Laboratory (lowa)

Argonne National Laboratory (Illinois)

Brookhaven National Laboratory (New York)

Fermi National Accelerator Lab.

(IIlinois)

Princeton Plasma Physics Lab. (New Jersey)

$E G$ and $G$ (Idaho)

Reynolds Electric and Engineering

Cumpany, Inc. (Nevada). 
Robert J. Hart, Manager Oak Ridge Operations Office United States

Department of Energy P.O. Box E

Oak Ridge, Tennessee 37830 (615) 576-4444 (Hart)

Alex G. Fremling, Manager Richland Operations Office United States

Department of Energy

P.O. Box 550

Richland, Washington 99852

(509) 942-7395

Joe LaGrone, Manager

San Francisco Operations Office

United States

Department of Energy

1333 Broadway - Wells Fargo Building

Oakland, California 94612

(415) 273-7111

Robert L. Morgan, Manager Savannah River Operations United States

Department of Energy

P.O. Box A

Aiken, South Carolina 29801

(803) 725-2277
Goodyear Atomic Corporation (Ohio)

National Lead Company of Ohio (Ohio)

Oak Ridge National Laboratory/Union

Carbide Corporation (Tennessee)

Oak Ridge Associated Universities, Inc.

(Tennessee)

Atlantic Richfield Hanford Co.

(Washington)

Battelle-Pacific Northwest Laboratory

(Washington)

United Nuclear Industries (Washington)

Westinghouse Electric Corporation (Washington)

Gulf Energy and Environmental

Systems (California)

Lawrence Berkeley Laboratory (California)

Lawrence Livermore Laboratory

(California)

Rockwell International Corporation/

Atnmirs International Divicion

(California)

Stanford Linear Accolerator Contcr

Calilornia

E. I. du Pont de Nemours and Company (South Carolina).

Savannah River Ecology Laboratory

(South Carolina) 